\title{
FLAVONOIDS OF THE SEEDS OF SOME SPECIES OF
}

THE FAMILY Cruciferae

V.S. Dolya, N.S. Fursa, and V. I. Litvinenko

UDC 547.97

Continuing a study of the seeds of plants of the family Cruciferae [1,2], by the chromatography on Kapron of an extract of Diplotaxis tenuifolia D.C. (slimleaf wallrocket) with elution by mixtures of chloroform and ethanol and then aqueous ethanol, we have isolated a compound with the composition $\mathrm{C}_{28} \mathrm{H}_{32} \mathrm{O}_{17}$, $\mathrm{mp} 209-211^{\circ} \mathrm{C}$ (from methanol), $[\alpha]_{\mathrm{D}}-56^{\circ}$ (c 0.1 ; methanol), $\mathrm{R}_{f} 0.64$ and 0.24 in the solvent systems $15 \%$ $\mathrm{CH}_{3} \mathrm{COOH}$ and BAW $(4: 1: 5)$, respectively. Qualitative reactions [3] and investigations of UV and IR spectra $[4,5]$ show that the substance is a flavonol glycoside with the carbohydrate component at $C_{3}$. On the bas is of the optical density of the glycoside and its aglycone $\left(E_{1}^{1} \% \mathrm{~cm}=250\right)$ it may be assumed that the glycoside isolated is a bioside [6]. The products of acid hydrolys is with $5 \% \mathrm{H}_{2} \mathrm{SO}_{4}$ were found to contain is orhamnetin and $\mathrm{D}$-glucose. On hydrolysis with $0.04 \mathrm{~N} \mathrm{HCl}$, an intermediate substance appeared coinciding in the

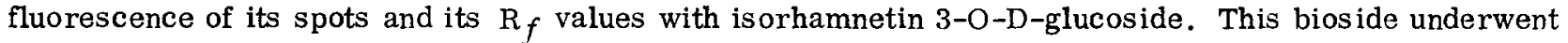
enzymatic cleavage with rhamnodias tase, which characterizes it as isorhamnetin 3-O-gentiobioside. Isorhamnetin derivatives have also been found in the seeds of Erysimum canescens Roth. (hoary erysimum), and quercetin derivatives both in the plants mentioned and in E. cheiranthoides L. (treacle erys imum), Capsella bursa pastoris Medic. (shepherd's purse), Lepidium perfoliatum L. (clasping pepperweed), and Syrenia cana Neilr.

\section{LITERATURE CITED}

1. V.S. Dolya, K. E. Koreshuk, N. S. Fursa, D. N. Golodner, and N. A. Kaminskii, Khim. Prirodn. Soedin., 386 (1972).

2. V. S. Dolya, E. N. Shkurupii, T. V. Podzolkova, and N. A. Kaminskii, Khim. Prirodn. Soedin., 15 (1973).

3. T. A. Geissman, in: Biochemical Methods of Plant Analysis [Russian translation], Moscow (1960), p. 403 .

4. V. I. Litvinenko and N. P. Maksyutina, Khim. Prirodn. Soedin., 420 (1965).

5. I. P. Kovalev and E. V. Titov, Atlas of Spectra [in Russian], Khar'kov (1966), p. 14.

6. N. P. Maksyutina and V. I. Litvinenko, in: Phenolic Compounds and Their Biological Functions [in Russian], Moscow (1968), p. 7.

Zaporozhe Medical Institute. Khar'kov Scientific-Research Institute of Pharmaceutical Chemistry . Translated from Khimiya Prirodnykh Soedinenii, No. 6, pp. 800-801, November-December, 1973. Original article submitted April 16, 1973.

(C) 1975 Plenum Publishing Corporation, 227 West 17th Street, New York, N.Y. 10011. No part of this publication may be reproduced, stored in a retrieval system, or transmitted, in any form or by any means, electronic, mechanical, photocopying, microfilming, recording or otherwise, without written permission of the publisher. A copy of this article is available from the publisher for $\$ 15.00$. 